\title{
Creating a space for indigenous rights: the Universal Periodic Review as a mechanism for promoting the rights of indigenous peoples
}

\section{Noelle Higgins}

To cite this article: Noelle Higgins (2019) Creating a space for indigenous rights: the Universal Periodic Review as a mechanism for promoting the rights of indigenous peoples, The International Journal of Human Rights, 23:1-2, 125-148, DOI: 10.1080/13642987.2018.1561438

To link to this article: https://doi.org/10.1080/13642987.2018.1561438

曲制 Published online: 11 Jan 2019.

Submit your article to this journal $\widetilde{ }$

Џ Article views: 162

View Crossmark data $\complement$ 


\title{
Creating a space for indigenous rights: the Universal Periodic Review as a mechanism for promoting the rights of indigenous peoples
}

\author{
Noelle Higgins \\ Department of Law, Maynooth University, Maynooth, Ireland
}

\begin{abstract}
In 2006, the Human Rights Council created a new method of overseeing the implementation of universal human rights standards, including the rights of indigenous peoples, in the form of the Universal Periodic Review (UPR). The UPR is a peer-review mechanism which requires States to report on their human rights practices in a variety of fields every 4-5 years and encourages other States to discuss, and make recommendations on, these reports. Since the UPR was created, every member state of the United Nations (UN) had been reviewed twice, and some have been reviewed 3 times. The paper analyses the first two cycles of the UPR to identify the ways in which indigenous peoples can play a role in the process, and also to query how the rights of indigenous peoples have been raised as part of this mechanism. The article will conclude with a number of recommendations as to how indigenous groups can engage with the UPR process to their benefit in the future.
\end{abstract}

\section{ARTICLE HISTORY}

Received 28 February 2018

Accepted 11 December 2018

\section{KEYWORDS}

Universal periodic review; peer-review; civil society; indigenous rights

\section{Introduction}

Created in 2006, the Universal Periodic Review (UPR) has as its aim an examination of the human rights practices and policies of all UN member states every 4 to 5 years. Its scope is universal, and thus includes themes that may not otherwise be reported on in other facets of the UN human rights framework, which is particularly important in the context of issues which are not specifically the subject of a core UN human rights treaty, such as the rights of indigenous peoples. The UPR has also opened up significant opportunities for the participation of non-governmental organisations (NGOs) and civil society groups in the state review process. This development provides an important avenue for the involvement of groups representing indigenous peoples within the UN human rights framework, and for the voices of indigenous peoples to be better heard within the organisation. This article explores the opportunities provided by the UPR to those who seek to promote and protect the rights of indigenous peoples. The first section sets out the how the UPR procedure operates. The next section then assesses how the UPR provides opportunities for NGOs representing indigenous peoples to advocate on behalf of the groups they represent. The third section discusses some of the recent practice relating

CONTACT Noelle Higgins noelle.higgins@mu.ie E Department of Law, Maynooth University, Maynooth, Ireland (C) 2019 Informa UK Limited, trading as Taylor \& Francis Group 
to indigenous peoples during the UPR process by highlighting some recommendations made by states on this issue throughout both of the completed cycles of the review. ${ }^{1}$ While there will be a disparity in the way in which different states engage with the UPR process, Australia was chosen as a lens through which to view the UPR mechanism in the context of indigenous peoples, as the government has provided informative updates on the implementation of UPR recommendations and there has been significant commitment by NGOs representing indigenous peoples in the process to date. The analysis of Australia's engagement with the process has been based on its state, NGO and UN reports submitted as part of the UPR process. Based on the analysis of the UPR and state practice to date, the Conclusion of the article provides some thoughts on the effectiveness of the UPR as a tool for promoting the rights of indigenous peoples, as well as recommendations as to how the full potential of the process can be harnessed for the benefit of indigenous peoples in the future.

\section{The UPR mechanism}

The UN created the Human Rights Council in $2006^{2}$ in response to many years of harsh criticism of the Human Rights Commission, ${ }^{3}$ and in an attempt to rebuild the institution's reputation as a protector and promoter of human rights. ${ }^{4}$ The Human Rights Council was mandated to

undertake a universal periodic review (UPR), based on objective and reliable information, of the fulfilment by each State of its human rights obligations and commitments in a manner which ensures universality of coverage and equal treatment with respect to all States. ${ }^{5}$

After much discussion and negotiation, ${ }^{6}$ the UPR mechanism was established through the adoption by the Human Rights Council of its 'institution-building package' in 2007, with the main objective of monitoring and improving human rights practices of all states, as well as measuring positive developments within states in the field of human rights, and facilitating the sharing of best practices between states. ${ }^{7}$

Because the aim of the UPR is the assessment of the 'fulfilment by each State of its human rights obligations and commitments', ${ }^{8}$ the Universal Declaration of Human Rights (UDHR) serves as a basis for the review, in addition to any other human rights instruments which have been ratified by the state under review, as well as applicable international humanitarian law, and any other commitments or pledges concerning human rights issues made by it. ${ }^{9}$ The UDHR does not contain any provisions which deal specifically with indigenous peoples, but Article 27(1), (which provides: 'Everyone has the right freely to participate in the cultural life of the community, to enjoy the arts and to share in scientific advancement and its benefits ${ }^{10}$ ), is relevant in reviewing how states deal with the rights of indigenous peoples. Other provisions of international human rights instruments, including the International Covenant on Civil and Political Rights (particularly Article 27), ${ }^{11}$ the International Labour Organisation (ILO) Convention No. $169,{ }^{12}$ and other core human rights treaties, ${ }^{13}$ can also be used as benchmarks against which to gauge how states protect and promote the rights of indigenous peoples. Furthermore, the United Nations Declaration on the Rights of Indigenous Peoples (UNDRIP), ${ }^{14}$ which was adopted in 2007, the year when the UPR was established, has been referred to 
throughout the UPR process as a framework which should inform state action with regard to indigenous peoples.

There are a number of different phases in the UPR process: Preparation, Interaction, Consideration, Adoption, and Implementation. ${ }^{15}$

\section{Preparation phase}

The first phase involves information gathering, whereby 3 reports on states' human rights policies and practices are complied. The first is completed by the state under review, the second consists of a summary of reports from other stakeholders including NGOs which deal with the rights of indigenous peoples, which is collated by the Office of the High Commissioner for Human Rights, and the third is based on information from independent human rights experts, human rights treaty bodies and other UN entities. In the context of indigenous peoples, this report could include state reports submitted to UN treaty body mechanisms, for example, reports to the Human Rights Committee, as well as information gathered through Special Procedure mechanisms, such as the Special Rapporteur on the Rights of Indigenous Peoples, in addition to other UN machinery such as the Expert Mechanism on the Rights of Indigenous Peoples.

\section{Interaction phase}

The interaction phase of the UPR takes places during a UPR Working Group session, when each state under review provides an oral report on their human rights policies and practices. Reviews are conducted by the UPR Working Group, i.e. the 47 members of the Human Rights Council. This is also named the 'interactive dialogue' phase of the review process, as representatives of any UN member state can ask questions and make comments and recommendations on the state under review's report and the other stakeholder information provided. While this is an important tool for facilitating discussion, tight time constrains apply and states under review are given a total of $70 \mathrm{~min}$ for presentation and discussion, and other states have a combined total of $140 \mathrm{~min}$ to make recommendations. These time limitations have resulted in 'many States not being able to speak at all, and diplomats lining up in the pre-dawn darkness to register to speak. ${ }^{16}$ Sweeney and Saito state that the limited time allowances led to 'a negative trend was established of "friendly States" filling the speakers' list to compliment the State under review." However, it should be noted that states which do not have a chance to speak during the interactive dialogue stage can submit their comments on the UPR's extranet. ${ }^{18}$

\section{Consideration and adoption phases}

Following the interactive dialogue session, the state under review can consider the recommendations made to it concerning its human rights policies and practices and can decide which ones it will support. A report is then completed by a 'Troika', i.e. three members of the Human Rights Council tasked with the role of preparing an 'Outcome Report', with the assistance of the Office of the High Commissioner for Human Rights. This provides a summary of the dialogue, and includes questions, comments and recommendations made to the state under review. No sooner than $48 \mathrm{~h}$ after the interactive 
dialogue session there is a further 30 min discussion on the adoption of the Outcome Report. During this time, the state under review may make preliminary comments on recommendations, stating whether it 'supports' or 'notes' recommendations. According to Resolution 5/1, the state under review cannot 'reject' recommendations but it can provide comments on recommendations which it notes, explaining why it does not support them. All of the recommendations made are included in the final Plenary Session Report of the Human Rights Council and the Outcome Report is adopted by the UPR Working Group. The state under review presents its response in an addendum to the Working Group, which is officially adopted at the Human Rights Council during a plenary session 3-4 months after the review in the Working Group.

\section{Implementation phase}

Focus then moves to the implementation of the UPR recommendations domestically. Unfortunately, while states can support numerous recommendations during the interactive phase, how these recommendations are implemented is not always clear because there is no official follow up mechanism within the UPR framework. States can choose to undergo a mid-term review, in order to report on how they have been implementing recommendations after 2 years. Up to 30 July 2018, 71 states had submitted UPR mid-term reports. 55 states submitted reports in relation to recommendations put forward during the first cycle of the UPR, 34 submitted reports in respect of Cycle 2 and 18 states submitted mid-term reports in relation to recommendations put forward during both cycles. ${ }^{19}$ Other stakeholders, including civil society and non-governmental organisations can also submit mid-term reports, commenting on the progress of state implementation of UPR recommendations. ${ }^{20}$

The Human Rights Council noted that Cycle 2 reports should particularly focus on implementation of Cycle 1 recommendations, and this focus on implementation will continue during future cycles. There have been numerous criticisms of the UPR because of the lack of consequences of non-implementation. Therefore, tracking of recommendations through to the implementation stage is very important. While some states take recommendations seriously and amend their domestic policies and practices in line with recommendations, other states take a more lax approach to the review process. States can defer any action on recommendations until just before their next review which can result in superficial and non-consultative changes in policy and legislation rather than a systemic change to the human rights environment. UPRInfo has attempted to address some of these problems by creating the Follow-up Programme in 2011 which encourages all UPR stakeholders to more actively participate in the follow-up to the UPR recommendations. ${ }^{21}$ It also developed the Implementation of the Recommendation Index in order to categorise the level of implementation for the UPR recommendations.

Cycle 1 of the UPR process began in 2008 and ended in 2011. 48 states were reviewed each year in different sessions of the Human Rights Council. The process was fine-tuned before the beginning of Cycle 2 in May 2012 which was completed in 2016, with some minor changes being made to the modalities, including an increase in the time dedicated to each state's review before the Human Rights Council and the subsequent extension of the timeframe of Cycle 2 from 4 to 4 and a half years. ${ }^{22}$ Cycle 3 is currently ongoing, beginning in 2017, and ending in 2021. Over Cycle 1 and Cycle 2, a total of 57,686 
recommendations were made and, while all 193 members of the UN were reviewed, almost all states also engaged in the UPR process by making recommendations to other states on a variety of issues, with only 22 states failing to make any recommendations at all. ${ }^{23}$

\section{The UPR architecture and indigenous peoples}

This article seeks to identify how indigenous peoples can utilise the UPR to its fullest potential in order to improve how states promote and protect their rights. In this context, it is important to note that the process does provide a space for the discussion of issues concerning indigenous peoples, in addition to opportunities for NGOs representing indigenous peoples to have a voice. This section provides a discussion of how indigenous peoples can contribute to the UPR process at each phase in order to benefit from this tool. According to Joshua Cooper, 'these five phases amount to a 24-month campaign that educates, engages, and empowers Indigenous Peoples to connect issues at the grassroots level with global governmental responsibility based on recommendations drafted in their own communities and countries. ${ }^{24}$

\section{Preparation phase}

It is important that indigenous peoples harness the potential of the UPR for their benefit by engaging in it to the fullest extent possible at each phase. With regard to the preparation phase, the UN provides guidance to states as to the format of their reports, including guidance on 'thematic clustering. ${ }^{25}$ The guidance note includes 'examples to States in the way in which the information provided in the national report may be thematically organized. ${ }^{26}$ There are divided into 5 areas, i.e. (a) 'cross cutting issues', (b) 'civil and political rights', (c) 'economic, social and cultural rights', (d) 'rights of specific persons or groups' and (e) 'specific regions or territories.' Of particular importance to the current discussion is the fact that under section (d) 'minorities and indigenous peoples' are specifically mentioned as groups on which states should provide information as part of their review. This is very significant given the fact that under the current UN core human rights treaty framework, there are no other specific reporting requirements on indigenous peoples. ${ }^{27}$ Under the UN treaty monitoring system, the rights of indigenous peoples are scantily protected and, while states are required to submit periodic reports under the nine core treaties which form part this system, none of these instruments deal significantly with the rights of indigenous issues. ${ }^{28}$ However, states have an opportunity to report on the rights of indigenous peoples under a number of provisions which form part of the treaty monitoring system, e.g. Article 27 of the International Covenant on Civil and Political Rights, ${ }^{29}$ various provisions of the International Covenant on Social, Economic and Cultural Rights, ${ }^{30}$ and the International Convention on the Elimination of All Forms of Racial Discrimination, ${ }^{31}$ the Convention on the Rights of the Child, ${ }^{32}$ and the Convention on the Rights of People with Disabilities, ${ }^{33}$ and some state reports to these treaty bodies include references to indigenous peoples. ${ }^{34}$ In this context, it is noted that Article 27 of the ICCPR has been used effectively in a number of cases concerning the rights of indigenous peoples and the Human Rights Committee has built up significant jurisprudence on this topic. ${ }^{35}$ Furthermore, a number of treaty monitoring bodies have developed indigenous rights through their analyses in General Comments. ${ }^{36}$ However, the treaty body monitoring mechanism can result 
in a fractured understanding of the rights of indigenous peoples. Certain states where indigenous peoples live may choose not to include indigenous issues in their reports, as there may be conflict between the group and the state. In addition, not every state with indigenous peoples has ratified the relevant UN treaties which would provide an outlet for the reporting on such groups. Therefore, it has been impossible to date to ascertain a universal picture of the rights of indigenous peoples. However, because the UPR applies to all member states of the United Nations and the reporting guidance includes a subsection on the rights of indigenous peoples, at the most basic level, additional information on the state of indigenous peoples globally can be distilled from this process. On a more advanced level, states can receive recommendations on indigenous peoples which can lead to an amendment of domestic policies and practices with regard to indigenous rights.

It is clear then that the UPR framework expects a discussion on indigenous rights when states in which indigenous peoples live are undergoing a review. However, in order to make the most of this discussion, NGOs representing indigenous peoples must prepare well to optimise the impact of the process. The preparation phase begins 18 months prior to a review and during the lead up to the review, it is vital that stakeholders, such as NGOs, educate the community about the work of the UPR, in order to encourage research and recording of state violations of the rights of indigenous peoples. It is an opportunity for stakeholders to hold consultations and write submissions which will contribute to the final Stakeholder report for the UPR. An interesting example of recording of state violations of the rights of indigenous peoples in the context of the UPR is the Testify Campaign co-ordinated by WITNESS and the US Human Rights Network, which collected video testimony from people across the United States, who shared their stories of human rights abuse during the preparation phase for America's review. ${ }^{37}$

It is important during the Preparation Phase that NGOs work together in order to share resources and knowledge in writing a submission to the UPR, and thus to increase impact. It is also key that when writing submissions (both for NGOs and states) that recommendations are written in a straight-forward and actionable way, as this will facilitate implementation. UPRInfo refer to these as SMART (specific, measurable, achievable, relevant, and time-bound) indicators. In this context UNDRIP should be used as a framework for recommendations, and its provisions referred to in recommendations for action.

It is essential that NGOs work with the government throughout the Preparation Phase to ensure that there is an open dialogue on priority issues for indigenous peoples. According to UPRInfo, 'the UPR has been successful in providing a platform for unprecedented dialogue between CSOs and governments', because '[g]overnments frequently appreciate that civil society is willing to seek compromises and solutions to common issues rather than embarking on naming and shaming campaigns. ${ }^{38}$

\section{Interaction phase}

During the Interaction Phase at Geneva, groups representing the rights of indigenous peoples can advocate effectively on behalf of indigenous peoples. In order to encourage effective engagement of NGOs, including those representing indigenous peoples, with the Interaction Phase, UPRInfo established UPR 'Pre-sessions' in 2012, at the start of 
the second UPR cycle. These meetings are open to a variety of stakeholders, including states, civil society organisations, national human rights institutions, academics, media, and UN bodies. UPRInfo invites the state under review to attend its own presession, and the majority of such states do attend. The Pre-sessions have a 'dual aim'; first, they provide civil society with an international platform to directly advocate to state delegations prior to the UPR session, and second, to allow diplomatic delegations to access information on states' human rights practices and policies. ${ }^{39}$ Instead of relying solely on the large number of UPR written submissions, the Pre-sessions provide states with the opportunity to hear directly from grass roots organisations about the human rights situation on the ground. According to UPRInfo, 'the ultimate aim of the Pre-sessions is to ensure that the recommendations that will be made at the Review are specific and well-targeted. ${ }^{40}$ These Pre-sessions take place in Geneva one month before the actual UPR Session and each one is country-specific, mirroring the actual UPR process. At the Pre-sessions, selected civil society organisations and national human rights institutions present on human rights issues which are important in the state under review, and then make a number of recommendations, which they would like the recommending states to make at the UPR. Given time restraints, not all civil society organisations can take part. ${ }^{41}$

In addition to the Pre-sessions, UPR Info also organises UPR training session the day before the Pre-sessions begin. The training sessions helps to prepare NGOs for their participation in the UPR process and to educate them as to how to employ advocacy strategies at the various stages of the UPR process. Groups representing indigenous peoples should take an active part in these UPRInfo initiatives, to focus attention on their priorities and to be well prepared for the UPR process.

NGOs representing indigenous peoples must also distil the priorities included in stakeholder reports to produce a succinct advocacy sheet which will facilitate a dialogue with diplomatic missions who are participating in the review in Geneva. Another way to highlight their priorities is to organise a Side Event, which focuses on the challenges facing indigenous peoples.

\section{Consideration and adoption phases}

Side Events can also be organised during the Consideration Phase, 'to allow impacted individuals to share stories with member states that can transform into real recommendations for change. ${ }^{42}$ A useful way to illustrate the importance of the UPR to indigenous communities is to organise a viewing of the state's review, which is broadcast live online, in local centres. This engages local communities and can encourage an interest in ensuring implementation of recommendations.

Once the review has been completed but before the report has been adopted, NGOs representing indigenous peoples can distribute the results of the Review and maintain pressure on states going forward into the implementation phase. During the Adoption phase, there are a small number of opportunities to make a 2 min intervention before the Human Rights Council in Geneva. NGOs representing indigenous peoples can take part in this or they can prepare a video to be shown instead of travelling to Switzerland. These sessions during the Adoption Phase are also webcast and so domestic screenings can also be organised in indigenous communities. 


\section{Implementation phase}

UPRInfo states that '[o]nce the state under review accepts a recommendation, the real work begins to build a culture of human rights by changing conditions through the realization of rights reflected in the recommendations. ${ }^{\prime 43}$ The level of implementation of recommendations varies hugely between states. This can depend on the subject-matter of the recommendation, the action called for, and indeed, the nature of the state. ${ }^{44}$ Consistent pressure by advocacy groups and the tracking of implementation of recommendations is necessary in order to make the UPR a successful tool for the promotion of the rights of indigenous peoples. Some organisations have produced templates which help track the implementation of recommendations, and accurately record the progress states have made. For example, Kenyan civil society stakeholders developed a document outlining how the recommendations received by the Kenyan government should be implemented. ${ }^{45}$ In addition, The Working Group on Human Rights in India and the UN (WGHR) developed a table incorporating information regarding the UPR recommendations, as well as possible actions on the recommendations, indicators that could help to monitor implementation, and also the government department or ministry responsible for the implementation. This document also includes a column that indicates the type of measures that have been taken by the state, thus helping to keep track of the progress made to date. ${ }^{46}$ Indigenous communities should be encouraged to prepare a similar template for recommendations pertaining to them.

UPRInfo also suggests that NGOs should ' $[w]$ hen possible, work with the government to ensure that implementation of recommendations is effective and sustainable. ${ }^{37}$ Nongovernmental organisations need to work with governments in order to implement recommendations if possible, by reminding them of their obligations, and informing the public of states' promises. ${ }^{48}$ Thus, representatives of indigenous should use the UPR as a framework for dialogue with state agencies.

\section{Indigenous peoples and the UPR: practice to date}

During both of the UPR cycles which have been completed to date, the rights of indigenous peoples have been regularly included in state reports, in the reports of stakeholders, and in recommendations made to states under review. This issue has been discussed during the interactive dialogue stage of the UPR and the recommendations made have led to states undertaking to change their policies and practices in respect of indigenous peoples.

UPRInfo, a non-governmental organisation which monitors the UPR process, has identified a total of 56 different 'issues' which have been raised in recommendations made to states under review as part of the UPR mechanism. The top 5 issues raised in the recommendations over the first two cycles were: 1. International instruments $(12,714) ; 2$. Women's rights $(10,718) ; 3$. Rights of the Child $(10,112) ; 4$. Torture and other Cruel, Inhumane and Degrading Treatment $(4,529)$ and 5 . Justice $(4,336) .{ }^{49}$ The issue of indigenous peoples came in 34th position, with a total of 999 recommendations being made over the two cycles, which amounted to $1.73 \%$ of the total recommendations made. ${ }^{50}$ It should be noted that the issue of minority rights comes in 10th position with 2,621 recommendations, amounting to $4.54 \%$ of the total recommendations made over 
the two cycles, and some of recommendations made in respect of minority rights may also have an impact on the rights of indigenous peoples. In Cycle 1, the issue of indigenous peoples was in 33rd position, with 389 recommendations, amounting to $1.82 \%$ of the total. The issue remained in 33rd position in Cycle 2, however while the number of recommendations rose to 610 , this amounted to a decrease in percentage share of total recommendations made at $1.68 \%$. This shows that while states are engaging more with the UPR process over time, and while more recommendations concerning indigenous peoples are being made, that unfortunately, overall, the importance of this issue has not increased from Cycle 1 to Cycle 2. Indeed, the fall in importance as expressed in percentage share of overall recommendations made is worrying, as the situation of indigenous peoples remains precarious in many states the world over and the topic needs additional attention at the UN. With fewer than $2 \%$ of all recommendations focusing on the rights of indigenous peoples, and that percentage falling between Cycle 1 and Cycle 2, it is clear that the UPR could be much better used as a tool to highlight the issue of indigenous rights going forward.

The first cycle of the UPR ran from 2008-2011. During this cycle 389 recommendations were made in respect of indigenous peoples. ${ }^{51} 81$ states made recommendations with regard to indigenous peoples and 55 states received recommendations on this topic. ${ }^{52}$ The states which made and received the most recommendations on indigenous peoples are as follows: ${ }^{53}$

Top 5 Receiving States

1. Australia (39)

2. Chile (30)

3. Canada (29)

4. Mexico (22)

5. Paraguay (20)
Top 5 Recommending States

1. Norway (38)

2. Mexico (30)

3. Bolivia (26)

4. Denmark (15)

5. Austria (15)

During the second cycle of the UPR, running from 2012-2016, the number of recommendations in respect of indigenous peoples increased to $610 .^{54}$ The number of states making recommendations on this issue rose to 121 and 78 states received recommendations on this topic. ${ }^{55}$ The states which made and received the most recommendations on indigenous peoples during this cycle are as follows: ${ }^{56}$

\begin{tabular}{ll}
\hline Top 5 Receiving States & Top 5 Recommending States \\
\hline 1. Canada (62) & 1. Mexico (28) \\
2. Australia (59) & 2. Norway (26) \\
3. New Zealand (33) & 3. Bolivia (23) \\
4. Costa Rica (29) & 4. Peru (17) \\
5. Chile (29) & 5. Uzbekistan (13) \\
\hline
\end{tabular}

One of the main issues which was raised in the UPR recommendations on indigenous peoples was the implementation of UNDRIP. ${ }^{57}$ UNDRIP provides a common frame of reference for all states, and a standard to which all states should aspire. For example, during Cycle 1, Denmark recommended that Australia take further steps to ensure the implementation of UNDRIP, and Ghana recommended that Australia '[e]nsure effective implementation of the Declaration on the Rights of Indigenous Peoples, including in the Northern Territory, and provide adequate support to the National Congress of Australia's First Peoples to enable it to address the needs of indigenous people'. In a similar 
vein, Mexico recommended to Belize that it ' $r$ ]edouble its efforts in favor of the respect of the rights of indigenous peoples, in line with the provisions of the United Nations Declaration on the Rights of Indigenous Peoples' and Pakistan recommended that Canada support and fully implement UNDRIP. During Cycle 2, Denmark recommended that the Russian Federation '[o]fficially endorse the United Nations Declaration on the Rights of Indigenous Peoples, and fully implement all relevant national laws and regulations' and Bolivia recommended to the United States that it '[i]mplement the United Nations Declaration on the Rights of Indigenous Peoples. ${ }^{58}$

However, while UNDRIP was referred to throughout the UPR process, a more direct and exact referencing to specific provisions of this instrument may have resulted in more specific action by states under review. While a number of issues that are covered in UNDRIP are raised in UPR recommendations, they are not always linked back to UNDRIP. For example, a number of recommendations focused on the question of indigenous lands, (an issue which is dealt with in Articles 8, 10, 25, 26, 27, 28, 29, 30, 32), including Slovenia's recommendation to Belize to protect Mayan customary property rights in accordance with Mayan customary laws and land tenure practices in consultation with affected Mayan people in Cycle $1 .^{59}$ In Cycle 2, Suriname accepted Canada's recommendation that it respect and ensure the rights of indigenous peoples related to the preservation of their land, culture and resources, ${ }^{60}$ but these recommendations did not specifically refer to the UNDRIP framework.

In addition, cultural sensitivity is another theme which can be identified in the recommendations concerning indigenous peoples, particularly, training as regards the culture and language of indigenous peoples for state officials (issues which are dealt with in Articles 8, 11, 13, 14, 15, 16, 31 of UNDRIP). For example, in Cycle 1 Austria recommended to Australia that it enhance the contacts and communication between Aboriginal and Torres Strait Islander communities and law enforcement officials and enhance the training of those officials with respect to cultural specificities of these communities. ${ }^{61}$ During Cycle 2, the Republic of Congo accepted a recommendation made by Sweden that it take additional steps for civic education and promote human rights awareness and ensure access to justice for indigenous groups. ${ }^{62}$ Again, the UNDRIP framework is not specifically mentioned.

Along with UNDRIP, another international legal instrument which featured a lot in the UPR recommendations regarding indigenous peoples is ILO Convention No. $169 .^{63}$ However, as with UNDRIP, this Convention was referred to in a general way rather than there being a focus on specific provisions. For example, during Cycle 1, Bolivia recommended to Australia that it ' $r$ ] atify ILO Convention No. 169 and incorporate it into its national norms', ${ }^{64}$ which was accepted by Australia. Mexico recommended to both Botswana and the Cameroon that they consider the ratification of this Convention, which was noted, rather than accepted in both cases. ${ }^{65}$ During Cycle 2, numerous other recommendations were made concerning the ratification of ILO Conventions, including a recommendation made by Uzbekistan to Sweden that it consider ratification of the ILO convention on indigenous peoples, ${ }^{66}$ which was accepted.

While each state will approach the UPR in its way, given the flexibility that is inherent in the mechanism, it is interesting to analyse how one state dealt with the process over the two cycles, to question how indigenous peoples played a role in it, and how the state dealt with recommendations regarding indigenous peoples. The state chosen for this analysis 
here is Australia. When UNDRIP was adopted in September 2007, Australia was among only four countries to vote against its adoption, along with New Zealand, the United States and Canada. However, following a changes of government, Australia changed its position and made a statement in support of the instrument on 3 April 2009, with the then Minister for Families, Community Services and Indigenous Services, Jenny Macklin, stating that UNDRIP 'Australia takes another important step in re-setting the relationship between Indigenous and non-Indigenous Australians and moving forward towards a new future ${ }^{67}$ Thus, Australia accepted it as a framework for better recognising and protecting the rights of Aboriginal and Torres Strait Islander Australians. The UPR can now facilitate a discussion of how Australia has addressed the rights of indigenous peoples which are protected in UNDRIP.

\section{Cycle 1}

The state report highlighted some planned and recently implemented initiatives with regard to indigenous Australians, including the planned recognition of Aboriginal and Torres Strait Islander peoples in the Constitution and the establishment of an Expert Panel on this recognition, ${ }^{68}$ the National Congress of Australia's First Peoples. ${ }^{69}$ A full section of the report is dedicated to 'Indigenous Australians', and a number of challenges facing indigenous peoples in Australia are mentioned, including disadvantages in education, employment, and health. The report refers to UNDRIP, stating that Australia gave its support to the instrument in April 2009, 'reaffirming the entitlement of Australia's Indigenous peoples to all human rights and fundamental freedoms, ${ }^{, 70}$ but it does not refer to specific provisions of the instrument.

The stakeholder report on Cycle 1 of the UPR contained a summary of the 14 submissions from 97 groups in total, illustrating that Australian NGOs felt that the UPR was an important process with which to engage. One of the joint submissions was prepared by NGOs working on the issue of indigenous rights, i.e. the Joint Submission submitted by the Aboriginal and Torres Strait Islander Legal Services of Australia (ATSILS) composed of: Aboriginal and Torres Strait Islander Legal Service (Qld) Ltd; Aboriginal Legal Rights Movement Inc; Aboriginal Legal Service (NSW/ACT); Aboriginal Legal Service of Western Australia (Inc.), Perth (Australia); Central Australian Aboriginal Legal Aid Service; North Australian Aboriginal Justice Agency; and Victorian Aboriginal Legal Service Co-operative Limited, Fitzroy, Victoria (Australia). The information provided in this report was much more detailed with regard to specific issues of concern facing indigenous peoples that the state report, including the establishment of a reparation scheme, ${ }^{71}$ and the principle of free, prior and informed consent of Aboriginal and Torres Strait Islander peoples in the development of policy that directly affect these communities. ${ }^{72}$ The report included recommendations from organisations ${ }^{73}$ that the government 'develop a framework to implement and raise awareness about' UNDRIP in consultation with Aboriginal and Torres Strait Islander peoples'. ${ }^{74}$ In a similar vein, OceaniaHR recommended that 'Australia should immediately create and coordinate a national implementation strategy plan to achieve the human rights of Aboriginal and Torres Strait Islanders recognized in the UNDRIP' ${ }^{75}$

The UN report on Australia for Cycle 1 of the UPR ${ }^{76}$ recalls that the Special Rapporteur on the Rights of Indigenous Peoples particularly noted the many instances of commitment 
made by the Australian government to reconcile with indigenous peoples, including its support for UNDRIP and the fact that he recommended that the Commonwealth and state governments should review all legislation, policies, and programmes that affect Aboriginal and Torres Strait Islanders, in light of the Declaration on the Rights of Indigenous Peoples, ${ }^{77}$ thus placing UNDRP at the centre of the discussion on indigenous peoples in Australia. It also references recommendation from other UN institutions in respect of indigenous Australians, including concerns about the serious limitations of the current Native Title Act framework which raised by Committee on the Elimination of All Forms of Racial Discrimination, the Human Rights Committee and the Committee on Economic, Social and Cultural Rights. ${ }^{78}$

During Cycle 1, 51 states made 162 recommendations to Australia. 144 recommendations were supported. Of these 162 recommendations, 39 related to indigenous peoples. This was the most common subject that was raised in recommendations. A number of these recommendations focused on the implementation of UNDRRIP, e.g. Denmark recommended that Australia 'take further steps to ensure the implementation of the Declaration on the Rights of Indigenous Peoples', Norway recommended that Australia 'fully implement the Racial Discrimination Act and the revision of federal laws to be compatible with the United Nations Declaration on the Rights of Indigenous Peoples', Bolivia recommended that Australia 'revise its Constitution, legislation, public policies and programmes for the full implementation of the United Nations Declaration of the Rights of Indigenous Peoples', Ghana recommended that Australia 'ensure effective implementation of the Declaration on the Rights of Indigenous People, including in the Northern Territory, and provide adequate support to the National Congress of Australia's First Peoples to enable it to address the needs of indigenous people', Hungary recommended that Australia 'develop a detailed framework to implement and raise awareness about the Declaration in consultation with indigenous peoples', and Guatemala recommended that Australia

launch a constitutional reform process to better recognize and protect the rights of the Aboriginals and Torres Strait Islanders which would include a framework covering the principles and objectives of the United Nations Declaration on the Rights of Indigenous Peoples and would take into account the opinions and contributions of indigenous peoples. ${ }^{79}$

Other issues were raised in the recommendations on indigenous peoples, including recommendations that Australia ratify ILO Convention No 169 (Bolivia and Norway), land rights (United Kingdom and Thailand), and education rights (Malaysia, Thailand, and Iran). ${ }^{80}$

However, while Australia supported all of these recommendations, apart from 1 (the recommendation by Slovenia that it establish a National Compensation Tribunal for indigenous Australia impacted by the state's assimilation policy), there was a gap in respect of implemented the recommendations. The Joint NGO Report on Australia's Human Rights Record provides an update on Australia's progress towards implementing Universal Periodic Review Cycle 1 recommendations. ${ }^{81}$ The Report notes that there had not been much progress made with regard to implementing the recommendations which had been made by the United Nations Special Rapporteur on the Rights of Indigenous Peoples following his 2009 visit, and significantly, the report also concludes that 'there has been limited incorporation of the Declaration on the Rights of Indigenous Peoples... into public 
policy or legislation. ${ }^{82}$ This report also states that there is a 'need for a formal commitment to the development of a national implementation strategy for' UNDRIP. ${ }^{83}$ However, it does set out some initiatives which the Australian government has taken in respect of indigenous peoples following on from the UPR, including some activity with regard to the operation of the native title system and the reinstatement of the Racial Discrimination Act 1975 in the Northern Territory. ${ }^{84}$ The Australian government has also taken a number of steps towards constitutional recognition of Aboriginal and Torres Strait Islander people, ${ }^{85}$ e.g. in 2010 Australia appointed an Expert Panel on Constitutional Recognition of Indigenous Australians to provide advice on the best way to provide recognition for Aboriginal and Torres Strait Islander peoples in the Constitution. Some of these moves reflect the rights enshrined in UNDRIP provisions, while others may have a more general aim, e.g. the purpose of consolidating anti-discrimination laws into one act was not specifically to ensure compatibility with UNDRIP, but this was one of the consequences. ${ }^{86}$

\section{Mid-term report}

Australia supported almost 95 per cent of the recommendations made during Cycle 1, and subsequently committed to using these recommendations to inform the development of the government's National Human Rights Action Plan. ${ }^{87}$ As part of its mid-term report to the Human Rights Council, Australia submitted the Action Plan; a document setting out 'Highlights regarding progress on Australia's National Human Rights Action Plan 2012'; and a 1 page explanatory note on the Action Plan. This latter document includes a number of important developments to be noted by the Human Rights Council, including the adoption of the Aboriginal and Torres Strait Islanders Peoples Recognition Act, which came into effect on 28 March 2013, and is identified as a first step towards constitutional recognition of Australia's first peoples. ${ }^{88}$

In the Action Plan, all of the UPR recommendations supported or partly supported by Australia during the UPR are tracked to specific legal and policy changes made / to be made in response to the recommendations, in addition to the agency leading the initiative and a timeline for implementation of the changes. Issues concerning indigenous Australians are referred to throughout the plan and there is also a discrete section entitled 'Aboriginal and Torres Strait Islander peoples'. This section states that '[c]urrent data shows a significant gap in these critical areas between Aboriginal and Torres Strait Islander and non-Indigenous populations, ${ }^{89}$ and sets out specific measures which are designed to 'close the gap' in addressing the disadvantages faced by indigenous Australians. This is a very useful document, to keep the government on track and to facilitate co-operation with NGOs working on the issues set out in the plan.

\section{Cycle 2}

Australia's state report for Cycle 2 highlights that the government has recognised the importance of working with NGOs throughout the UPR process. Paragraph 10 states that

As with Australia's response to its first review, this national report was developed following consultations across the Australian Government, and state and territory governments. The 
views of peak non-government organisations (NGOs) on a draft version of the report were sought at, and following, the Australian Government's annual NGO forum on human rights. The Australian Attorney-General, Senator the Hon George Brandis QC, also subsequently met with peak NGOs to discuss the report and has committed to engaging with the NGO sector throughout the process. Following Australia's second UPR the Government intends to once again engage with NGOs and the AHRC in relation to recommendations it receives. ${ }^{90}$

This illustrates an excellent opportunity for groups representing indigenous Australians to engage with government on their priority issues.

As requested by the Human Rights Council, the report focuses on how the government implemented recommendations to the state from Cycle 1. The state report thus tracks the recommendations made in Cycle 1 and notes progress made in relation to these recommendations. The first issue which the 2 nd state report focuses on is giving constitutional recognition to indigenous Australians (Recommendations 103-105 and 107 from Cycle 1). Constitutional recognition had not been granted by the time of the 2nd review, but the government states that it is strongly committed to holding a referendum to recognise Indigenous Australians in the Constitution.' 91

The rights of indigenous Australians is also dealt within the report's section on Equality and Non-discrimination. The reports highlights that the government has an agenda for reform in the rights of indigenous Australians in the areas of: ensuring children go to school; getting adults into work; making sure communities are safer to live in and that the rule of law is applied; and achieving constitutional recognition for Aboriginal and Torres Strait Islander peoples. ${ }^{92}$ These issues echo provisions of UNDRIP, although the report does specifically identify the relevant provisions (Article 14 (education); Article 3, Article 5 (economic development); Article 1 (rule of law). However, the report reiterates that: 'Australia continues to support the United Nations Declaration on the Rights of Indigenous Peoples as a set of important guiding principles for the Government's engagement with Indigenous Australians. ${ }^{93}$

The report deals with indigenous peoples under other sections of the report, e.g. 'Justice and the Rule of Law'

The Australian Government will continue to directly fund Indigenous legal assistance providers in line with the Government's Indigenous affairs priorities and ongoing commitment to improving law and justice outcomes for Indigenous Australians. The Government will invest $\$ 358$ million over five years in legal assistance services to Indigenous Australians), ${ }^{94}$

'Social Security' ('the Australian Government provides a range of payments and services to Australians, including retirees, the unemployed, families, carers, parents, persons with disabilities, students, and Indigenous people'), ${ }^{95}$

While the state report records progress it has made in the field of indigenous rights it does not say that initiatives in respect of indigenous peoples are set up specifically as a result of the UPR process, nor, predictably, does it identify the areas in which it has not made progress and which recommendations it has failed to implement, e.g. no mention is made of the non-ratification of ILO Convention No. 169.

The stakeholder report ${ }^{96}$ for the second cycle included a summary of 22 stakeholders' submissions. 16 groups made individual submissions, and 5 joint submissions were made by numerous NGOs. One joint submission was made which summarised submissions made by 190 NGOs working on a variety of issues, including groups focusing on the 
rights of indigenous Australians. 14 submissions referred to indigenous related issues, ${ }^{97}$ and one section of the report is entitled 'Indigenous peoples', although issues facing indigenous Australians are also picked up in other parts of the report. The section on 'Indigenous peoples' relays some of the progress made by the government since the previous UPR cycle (e.g. the adoption of the World Conference of Indigenous Peoples Outcome Document), ${ }^{98}$ but also highlights the lack of implementation of some of the UPR recommendations. One of the submissions raised the issue that Australia was impeding the right to self-determination of indigenous peoples 'by continuing to impose forced integration on its peoples'. ${ }^{99}$ However, the report does not refer to UNDRIP in this context. It does, however, refer to the Declaration in regard to the strict requirement of the Native Title Act 1993 (Cth) of continuous connection to the land since colonisation and states that it was incompatible with UNDRIP. The report also records that the Australian Human Rights Commission recommends that the government develop, in partnership with indigenous Australians, a National Strategy to give effect to UNDRIP.

The UN report ${ }^{100}$ summarises the interactions of a number of UN institutions with the Australian government. In the context of indigenous Australians, this focused on the Committee on the Rights of the Child, which noted inadequate consultation and participation of Aboriginal and Torres Strait Islander persons in the policy formulation, decision-making and implementation processes of programmes affecting them'. ${ }^{101}$ The Committee was also concerned at the large numbers of indigenous children being separated from their homes and communities and placed into care that, where the preservation of their cultural and linguistic identity was not facilitated. It recommended that Australia review its progress in implementing the recommendations in the report 'Bringing them home: national inquiry into the separation of Aboriginal and Torres Strait Islander children from their families'. 102

The report also reiterates the Committee on the Elimination of Racial Discrimination's statement on the need to guarantee the free, prior and informed consent of the communities concerned. ${ }^{103}$ The report also refers to the Special Rapporteur on the Rights of Indigenous Peoples and his comments that the government should maintain ongoing consultations with Aboriginal peoples concerning the implementation of the Stronger Futures legislation. ${ }^{104}$

The section concerning indigenous peoples does not refer to UNDRIP, but the instrument is referred to in the section on 'Constitutional and Legislative Framework', where it notes that in June 2015, the United Nations High Commissioner for Human Rights welcomed proposals to introduce a reference to the United Nations Declaration on the Rights of Indigenous Peoples in the Human Rights (Parliamentary Scrutiny) Act.

Cycle 2 saw an increase in recommendations made to Australia in respect of indigenous peoples to 59.15 of these recommendations were noted, but all of the rest were accepted. UNDRIP again was the focus of a number of recommendations made to Australia in respect of indigenous peoples. Senegal recommended that Australia 'adhere to' UNDRP, Estonia recommended that Australia to 'develop in partnership with Aboriginal and Torres Strait Islander peoples a National Strategy to give effect to the United Nations Declaration on the Rights of Indigenous Peoples, and to facilitate the constitutional recognition of Aboriginal Australians', and Hungary once again recommended that Australia 'develop, in partnership with indigenous communities, a national strategy to implement the United Nations Declaration on the Rights of Indigenous Peoples' ${ }^{105}$ Other issues 
which were raised include, once again, the ratification of ILO Convention No. 169 (Chile), and constitutional recognition of indigenous Australians (Georgia, Sri Lanka, Republic of Korea and Estonia). ${ }^{106}$

A number of states raised concerns in relation to Australia's treatment of indigenous peoples, including high-levels of discrimination against Aboriginal and Torres Strait Islander peoples (Japan), disproportionately high rates of indigenous incarceration (Norway), however, as before, there was a lack of reference to specific provisions of UNDRIP. In response to the UPR Cycle 2 recommendations, Australia reaffirmed its commitment to improving the situation of indigenous Australians, including implementing its Indigenous Strategy 2015-2019. However, a number of major problems continue to exist, including in the areas of discrimination, health, life expectancy, education justice etc. ${ }^{107}$

The case study of Australia illustrates that the UPR can be beneficial to indigenous peoples by opening and / or maintaining a dialogue between the government on indigenous rights and priorities, by facilitating discussion and collaboration between NGOs working on indigenous issues, and by concerting pressure on the Australian government to constantly improve. Australia is to be commended for its mid-term report to the UN Human Rights Council on Cycle 1 recommendations and its Action Plan, which clearly tracks UPR recommendations. This is an excellent initiative and provides a framework for consistent improvement in the field of the rights of indigenous peoples. However, despite this, Australia was slow in implementing some Cycle 1 recommendations and others had not been addressed by the time of writing the mid-term report or the Cycle 2 report. In addition, Australia has not submitted a mid-term report in respect of Cycle 2 of the UPR, and so it is difficult to make conclusions on the actual impact of the UPR in this state. What is clear is that is that lobbying on the part of indigenous rights groups in respect of the UPR recommendations is needed in order to maintain pressure on the government to fulfil its UPR promises.

\section{Conclusion}

At the outset, there were high hopes for the success of the UPR process and it was heralded by UN officials as a very positive addition to the UN human rights monitoring framework, with former Secretary-General Ban Ki-moon stating in 2007 that the UPR had 'great potential to promote and protect human rights in the darkest corners of the world. ${ }^{\text {,108 }}$ Now that 2 cycles have been completed, some observations can be made in respect of the process's effectiveness. To date, there has been a certain amount of ambivalence towards the process from non-governmental groups and academics alike. One of the main criticisms levelled at the process is that states are 'soft' with their recommendations to neighbouring and / or friendly states, with Abebe commenting that ' $\mathrm{t}$ ] $\mathrm{here}$ are ominous signs that the problem of regional block voting, which had seriously afflicted the former Commission, remains a formidable challenge to the Council's decision making process. ${ }^{109}$ This situation led UN Watch to report in 2009 that the UPR facilitated a 'mutual praise society', ${ }^{110}$ rather than acting as a strong accountability tool. Unfortunately, if this is the case, it is doubtful if a genuine appraisal of the rights of indigenous peoples can be encouraged by this process.

However, other reviews of the UPR have highlighted positive aspects of this review process. For example, Frazier states that 'the UPR has been effective in promoting 
human rights in the short term. It has helped to highlight serious human rights violations and has done so in a public forum that allows debate to occur on the best way to address those problems. The UPR has also helped to give countries specific guidance, and individualized, achievable goals to meet in progressing respect for human rights; goals which many countries have met or are in the process of meeting. ${ }^{111}$

While a number of commentaries adopted a 'wait and see' approach, ${ }^{112}$ as time has passed commentaries have generally been more positive towards the UPR, ${ }^{113}$ as observers have had the opportunity to evaluate the implementation of UPR recommendations, ${ }^{114}$ which show that states have, to a significant extent, seriously considered recommendations made to them by other states during the UPR process and have amended some of their policies and practices accordingly. ${ }^{115}$ Recommendations made as part of the UPR process have influenced domestic practice through amendment of domestic laws, ratification of international instruments and changes in governmental policies in a number of states. However, states have taken different approaches to recording how they have implemented the recommendations which they have accepted as part of the UPR process. Unfortunately, the mid-term assessment is currently optional, and thus some states may delay reviewing the UPR recommendations which they accepted until close to their second review. What would be very help in this context is first, making the mid-term review a requirement of the UPR process, and second, the adoption of an implementation template, applicable to all states, whereby all states would be require to 'map' their actions, in terms of adoption of legislation, policy changes, institution building, in response to their accepted UPR accepted recommendations. This would allow for a clearer analysis of improvement (or otherwise) in states' human rights practices. Some states have adopted a very clear tracking approach, ${ }^{116}$ e.g. Kenya has prepared an 'Implementation Matrix', which illustrates the domestic measures taken as a result of the recommendations made. ${ }^{117}$ Another effective model is used in Paraguay, known as SIMORE, ${ }^{118}$ which is coordinated by the Ministry of Foreign Affairs and the Ministry of Justice. Groups representing indigenous peoples should also track UPR recommendations which relate to indigenous rights, to ensure that UPR commitments are not forgotten or pushed aside. In addition, UNDRIP provisions should be explicitly referred to when recommendations concerning the rights of indigenous peoples are made (both by states and NGOs), to highlight the importance of this instrument as an expression of indigenous rights and to ensure consistency across the board.

One of the most positive aspects the UPR process is that it provides a space for civil society and non-governmental organisations to participate in the review. A central issue with regard to the current framework seeking to promote and protect the rights of indigenous peoples is its state-centric nature. This means that the voice of indigenous peoples can be difficult to heard, as they can generally only participate indirectly in the system, via state representatives. ${ }^{119}$ If there is a confrontational relationship between states and an indigenous group, it is difficult for the rights of that group to be raised before the UN system. However, with the UPR, indigenous groups can organise and advocate on their own behaves and contribute to the stakeholder report. Unfortunately, Universal Rights Group has commented that 'these crucial "shadow" reports are not fulfilling that function.' ${ }^{120}$ Therefore, additional work is needed to prepare stakeholders to contribute in a more effective way to these reports. One option for indigenous groups is to take advantage of the tools and training sessions offered by UPRInfo, described above, in order to be well 
prepared for the UPR process and optimise its benefits. Given the nature of the UPR, which facilitates interactive dialogue and lesson learning between groups, indigenous groups can learn from one another and share advice. The UPRInfo Pre-sessions are an opening to learn lessons from each other and to strengthen advocacy on behalf of indigenous peoples.

According to Indigenous World in 2011, the UPR process was a 'limited success'. ${ }^{121}$ More encouragingly, in 2014 Joshua Cooper characterised the UPR as 'a potent process for the realization of human rights in indigenous homelands. ${ }^{122} \mathrm{He}$ also stated that:

The ultimate aspiration of the Universal Periodic Review is the improvement of human rights in every country with significant consequences for people around the globe. If Indigenous Peoples participate in each phase, there will be a rigorous review and the results will be substantive. It can become a regular measure of how states are implementing the rights enshrined in the Declaration, and it can be the catalyst for the conversation with a country's leadership to ensure the Declaration is beyond paper, building better lives for Indigenous Peoples.'

If groups representing indigenous peoples embrace the opportunities provided by the UPR process to engage in stakeholder reports, to track recommendations to implementation and to maintain pressure on states to fulfil UPR commitments, the UPR can indeed be a powerful tool for improving their rights worldwide in the future. ${ }^{123}$

\section{Notes}

1. The NGO UPRInfo provides excellent online tools, which facilitate searches for keywords raised and recommendations made during the UPR.

2. UNGA Res 60/251, 15 March 2006. With regard to the history and functions of the Human Rights Council, see P.J. Flood, 'The U.N. Human Rights Council: Is its Mandate WellDesigned?', ILSA Journal of International and Comparative Law 15 (2008-2009): 472-84 and J. Matiya, 'Repositioning the International Human Rights Protection System: The UN Human Rights Council', Commonwealth Law Bulletin 36, no. 2 (2010): 313-24.

3. See H. Boekle, 'Western States, the UN Commission on Human Rights and the "1235" Procedure: The Question of Bias Revisited', Netherlands Quarterly of Human Rights 13 (1995): 367-402 and T. Franck, 'Of Gnats and Camels: Is there a Double Standard in the United Nations?', American Journal of International Law 78 (1984): 811-34. For a discussion of the transition from the Human Rights Commission to the Human Rights Council, see P.G. Lauren, 'To Preserve and Build on its Achievements and to Redress its Shortcomings: The Journey from the Commission on Human Rights to the Human Rights Council', Human Rights Quarterly 29 (2007): 307-45.

4. The Human Rights Council replaced the Human Rights Commission by virtue of UN General Assembly Resolution 60/251 (2006). See generally, B. Ramcharan, The UN Human Rights Council (UK: Routledge, 2011); M. Bossuyt, 'The Human Rights Council: A First Appraisal', Netherlands Quarterly of Human Rights 24, no. 4 (2006): 551-5 and N. Schrijver, "The UN Human Rights Council: A New "Society of the Committed" or Just Old Wine in New Bottles?', Leiden Journal of International Law 20, no. 4 (2007): 809-23.

5. UNGA Res 60/251, 15 March 2006. For a discussion of the UPR see P.J. Flood, 'The U.N. Human Rights Council: Is its Mandate well-designed?', ILSA Journal of International and Comparative Law 15 (2008-2009): 472-84 and E. McMahon and M. Ascherio, 'A Step Ahead in Promoting Human Rights? The Universal Periodic Review of the UN Human Rights Council', Global Governance 18 (2012): 231-48.

6. Different States had varying views on the format they hoped the UPR would take. See Human Rights Peer Review, Draft Concept and Opinions Paper, prepared by Canada, 29 April 2005, 
at para. 9, www.humanrightsvoices.org/assets/attachments/documents/human_rights_peer_ review_canada.pdf (accessed February, 2018).

7. UN Human Rights Council, 'Institution-building of the United Nations Human Rights Council', HRC Res 5/1 UN GAOR, 5th Sess., 9th mtg., (2007) 1 UN Doc A/HRC/5/1.

8. UN Human Rights Council, 'Institution-building of the United Nations Human Rights Council', HRC Res 5/1 UN GAOR, 5th Sess., 9th mtg., (2007) 1 UN Doc A/HRC/5/1.

9. Human Rights Council Resolution 5/1, annex at 1.A.1.

10. Universal Declaration of Human Rights, proclaimed by the United Nations General Assembly in Paris on 10 December 1948 (General Assembly resolution 217 A).

11. International Covenant on Civil and Political Rights, adopted by General Assembly resolution 2200A (XXI), 16 December 1966.

12. ILO Convention No. 169, Convention concerning Indigenous and Tribal Peoples in Independent Countries 1989.

13. For example, some regional instruments protect indigenous peoples' rights, including the African Charter on Human and Peoples' Rights (adopted 27 June 1981) OAU Doc CAB/ LEG/67/3 rev. 5, 21 ILM 58 (1982).

14. United Nations Declaration of the Rights of Indigenous Peoples, adopted by General Assembly resolution 61/295, 2007.

15. See: J. Cooper, 'Universal Periodic Review: A Potent Process for the Realization of Human Rights in Indigenous Homelands', Cultural Survival Quarterly Magazine 38(2) (2014), https://www.culturalsurvival.org/publications/cultural-survival-quarterly/universalperiodic-review-potent-process-realization-human (accessed July, 2018).

16. E. McMahon, 'Herding Cats and Sheep: Assessing State and Regional Behavior in the Universal Periodic Review Mechanism of the United Nations Human Rights Council', www. upr-info.org/IMG/pdf/McMahon_Herding_Cats_and_Sheeps_July_2010.pdf, 12 (accessed February, 2018).

17. G. Sweeney and Y. Saito, 'An NGO Assessment of the New Mechanisms of the UN Human Rights Council', Human Rights Law Review 9, no. 2 (2009): 203-23, 210.

18. The UPR Extranet is http://www.ohchr.org/EN/HRBodies/UPR/Pages/UPRRegistration. aspx (accessed July, 2018).

19. See United Nations Human Rights Council, 'UPR Mid-term Reports', http://www.ohchr.org/ EN/HRBodies/UPR/Pages/UPRImplementation.aspx. These mid-term reports are http:// www.ohchr.org/EN/HRBodies/UPR/Pages/UPRImplementation.aspx (accessed July, 2018).

20. See United Nations Human Rights Council, 'UPR NGOs Mid-term Reports', http://www. ohchr.org/EN/HRBodies/UPR/Pages/UPR-NGOs-Mid-term-reports.aspx (accessed July, 2018).

21. UPRInfo, 'Follow-up Programme', https://www.upr-info.org/followup/ (accessed July, 2018).

22. See resolution 16/21, 15 March 2011 and decision 17/119.

23. https://www.upr-info.org/database/statistics (accessed July, 2018).

24. J. Cooper, 'Universal Periodic Review: A Potent Process for the Realization of Human Rights in Indigenous Homelands', Cultural Survival Quarterly Magazine 38(2) (2014), https://www. culturalsurvival.org/publications/cultural-survival-quarterly/universal-periodic-reviewpotent-process-realization-human (accessed July, 2018).

25. See United Nations Office of the High Commissioner on Human Rights, '3rd Cycle Universal Periodic Review National Report - Guidance Note', www.ohchr.org/Documents/ .../3rdCycle_GuidanceNotePreparationReports_EN.docx (accessed July, 2018).

26. See United Nations Office of the High Commissioner on Human Rights, '3rd Cycle Universal Periodic Review National Report - Guidance Note', www.ohchr.org/Documents/ .../3rdCycle_GuidanceNotePreparationReports_EN.docx (accessed July, 2018).

27. Under Article 22 of the ILO Constitution, each Member State must provide periodic reports to the International Labour Office on ratified conventions, setting out the measures taken to implement the provisions of those Conventions it has ratified.

28. See B. Saul, Indigenous Peoples and Human Rights (London: Hart Publishing, 2016) and B. Saul, 'Introduction: Indigenous Peoples and Human Rights - Institutions and Influences', 
Sydney Law School, Legal Studies Research Paper No. 16/39, May 2016, https://ssrn.com/ abstract=2778903 (accessed February, 2018).

29. This provision states that ' $[\mathrm{i}] \mathrm{n}$ those States in which ethnic, religious or linguistic minorities exist, persons belonging to such minorities shall not be denied the right, in community with the other members of their group, to enjoy their own culture, to profess and practise their own religion, or to use their own language'. Article 27 International Covenant on Civil and Political Rights, adopted by General Assembly resolution 2200A (XXI), 16 December 1966.

30. International Covenant on Economic, Social and Cultural Rights, adopted by General Assembly resolution 2200A (XXI), 16 December 1966. While no provisions of this instrument specifically refer to indigenous peoples, numerous of its provisions are of relevance to indigenous peoples, including Article 15(1), which states: 'The States Parties to the present Covenant recognize the right of everyone: (a) To take part in cultural life ...'

31. International Convention on the Elimination of All Forms of Racial Discrimination, adopted General Assembly resolution 2106 (XX) of 21 December 1965. As with the International Covenant on Economic, Social and Cultural Rights, no provisions of this instrument explicitly deal with indigenous peoples. However, a number of provisions are relevant to this group, including Article 2(1), which states: 'States Parties condemn racial discrimination and undertake to pursue by all appropriate means and without delay a policy of eliminating racial discrimination in all its forms and promoting understanding among all races'.

32. Convention on the Rights of the Child, adopted by General Assembly resolution 44/25 of 20 November 1989. Articles 17, 29 and 30 specifically mention indigenous peoples. Article 30 states: 'In those States in which ethnic, religious or linguistic minorities or persons of indigenous origin exist, a child belonging to such a minority or who is indigenous shall not be denied the right, in community with other members of his or her group, to enjoy his or her own culture, to profess and practise his or her own religion, or to use his or her own language'.

33. See Preamble, Convention on the Rights of People with Disabilities, adopted by General Assembly resolution A/RES/61/106 of 13 December 2006.

34. For example, the 6th state report from New Zealand on the ICCPR to the Human Rights Committee contains numerous references to the Māori population and discusses various topics, including education, incarceration rates, equality, language, political representation, amongst others. CCPR/C/NZL/6, 24 July 2015.

35. See B. Saul, Indigenous Peoples and Human Rights (Hart Publishing, London, 2016) and A. Xanthaki, 'Indigenous Rights in International Law over the Last 10 Years and Future Developments: Reflections on a Decade of International Law', Melbourne Journal of International Law 10 (2009): 27-37.

36. This can be seen from the work of the Committee on Economic, Social and Cultural Rights, which, in General Comment No 14, recognised the rights of indigenous peoples to control their own health services and to have medical care delivered in a manner which is culturally appropriate. CESCR, General Comment No 14: The Right to the Highest Attainable Standard of Health (Article 12 of the International Covenant on Economic, Social and Cultural Rights), 22"d sess, Agenda Item 3, UN Doc E/C. 12/2000/4 (11 August 2000). See A. Xanthaki, 'Indigenous Rights in International Law over the Last 10 Years and Future Developments: Reflections on a Decade of International Law', Melbourne Journal of International Law 10 (2009): 27-37, 28.

37. https://witness.org/portfolio_page/monitoring-human-rights-united-states/ (accessed July, 2018).

38. UPRInfo, 'The Butterfly Effect', (UPRInfo Geneva, 2016), iv.

39. https://www.upr-info.org/en/upr-process/pre-sessions (accessed July, 2018).

40. Ibid.

41. Priority is given on the following bases: Grassroots and national CSOs; National coalitions; CSOs that have submitted a report to the UPR and are committed to engaging in the process, in particular in the implementation phase; A broad representation of the various human 
rights issues representing the concerns of the local population. In particular, a balance is sought amongst civil and political rights, and economic, social and cultural rights; and ensuring a gender perspective for each Pre-sessions; where possible, gender parity amongst panellists is also sought.

42. J. Cooper, 'Universal Periodic Review: A Potent Process for the Realization of Human Rights in Indigenous Homelands', Cultural Survival Quarterly Magazine 38(2) (2014), https://www. culturalsurvival.org/publications/cultural-survival-quarterly/universal-periodic-reviewpotent-process-realization-0 (accessed July, 2018).

43. Ibid.

44. See S. Gujadhur and M. Limon for Universal Rights Groups, 'Towards the Third Cycle of the UPR: Stick or Twist' (2016), https://www.universal-rights.org/wp-content/uploads/2016/07/ URG_UPR_stick_or_twist.pdf (accessed July, 2018), p. 5.

45. See: From commitments to actions: the stakeholder's outcomes charter on the UPR of Kenya', http://s.upr-info.org/kenyacharter (accessed July, 2018).

46. See: WGHR Press Release, Comprehensive review of India's human rights record at the UN Human Rights Council: Glaring Omissions, Some Progress, September 21, 2012, http://www. wghr.org/pdf/WGHR\%20UPR\%20press\%20release\%20 21.09.2012.pdf (accessed July, 2018).

47. UPRInfo, 'Beyond Promises', https://www.upr-info.org/sites/default/files/general-document/ pdf/2014_beyond_promises.pdf (accessed July, 2018), p. 8.

48. UPRInfo, 'Beyond Promises', https://www.upr-info.org/sites/default/files/general-document/ pdf/2014_beyond_promises.pdf (accessed July, 2018), p. 64.

49. https://www.upr-info.org/database/statistics (accessed July, 2018).

50. Ibid.

51. Ibid.

52. Ibid.

53. Ibid.

54. Ibid.

55. Ibid.

56. Ibid.

57. United Nations Declaration of the Rights of Indigenous Peoples, adopted by General Assembly resolution 61/295, 2007.

58. https://www.upr-info.org/database/index.php?\&limit=0\&f_SUR=All\&f_SMR=All\&order= \&orderDir $=$ ASC\&orderP=true\&f_Issue $=26 \&$ searchReco $=\&$ resultMax $=100 \&$ response $=$ \&action_type $=\&$ session $=\&$ SuRRgrp $=\&$ SuROrg $=\& S M R$ Rrp $=\& S M R O r g=\&$ pledges $=$ RecoOnly (accessed July, 2018).

59. Ibid.

60. Ibid.

61. Ibid.

62. Ibid.

63. ILO Convention No. 169, Convention concerning Indigenous and Tribal Peoples in Independent Countries 1989.

64. https://www.upr-info.org/database/index.php?\&limit=0\&f_SUR=All\&f_SMR=All\&order= \&orderDir $=$ ASC\&orderP=true\&f_Issue $=26 \&$ searchReco $=\&$ resultMax $=100 \&$ response $=$ \&action_type $=\&$ session $=\&$ SuRRgrp $=\&$ SuROrg $=\&$ SMRRgrp $=\&$ SMROrg $=\&$ pledges $=$ RecoOnly (accessed July, 2018).

65. Ibid.

66. Ibid.

67. Reconciliation Australia, 'The United Nations Declaration on the Rights of Indigenous Peoples (UNDRIP)', p. 1, https://www.reconciliation.org.au/wp-content/uploads/2017/11/ Reconciliation-Australia-United-Nations-Declaration-on-the-Rights-of-IndigenousPeoples-UNDRIP.pdf (accessed July, 2018).

68. National report submitted in accordance with paragraph 15 (a) of the annex to Human Rights Council resolution 5/1, Australia, A/HRC/WG.6/10/AUS/1, 5 November 2010, para. 14 . 
69. Ibid, para. 35 .

70. Ibid, para. 59 .

71. Summary prepared by the Office of the High Commissioner for Human Rights in accordance with paragraph 15 (c) of the annex to Human Rights Council resolution 5/1, Australia, A/ HRC/WG.6/10/AUS/3, 11 November 2011, para. 52.

72. Ibid, para. 56 .

73. Joint Submission submitted by the Aboriginal and Torres Strait Islander Legal Services of Australia (ATSILS) composed of: Aboriginal and Torres Strait Islander Legal Service (Qld) Ltd; Aboriginal Legal Rights Movement Inc; Aboriginal Legal Service (NSW/ACT); Aboriginal Legal Service of Western Australia (Inc.), Perth (Australia); Central Australian Aboriginal Legal Aid Service; North Australian Aboriginal Justice Agency; and Victorian Aboriginal Legal Service Co-operative Limited, Fitzroy, Victoria (Australia).

74. Summary prepared by the Office of the High Commissioner for Human Rights in accordance with paragraph 15 (c) of the annex to Human Rights Council resolution 5/1, Australia, A/ HRC/WG.6/10/AUS/3, 11 November 2011, para. 55.

75. Ibid.

76. Compilation prepared by the Office of the High Commissioner for Human Rights in accordance with paragraph 15 (b) of the annex to Human Rights Council resolution 5/1, Australia, A/HRC/WG.6/10/AUS/2, 15 November 2010.

77. Ibid, para. 41.

78. Ibid, para. 43 .

79. See UPRInfo, 'Database of Recommendations', https://www.upr-info.org/database/index. php?\&limit=0\&f_SUR=9\&f_SMR $=$ All\&order $=\&$ orderDir $=$ ASC\&orderP $=$ true $\& f$ Issue $=$ 26\&searchReco=\&resultMax $=100 \&$ response $=\&$ action_type $=\&$ session $=1-2-3-4-5-6-7-8-9$ $10-11-12 \&$ SuRRgrp $=\&$ SuROrg $=\& S M R R g r p=\& S M R O r g=\& p l e d g e s=$ RecoOnly $\quad$ (accessed July, 2018).

80. Ibid.

81. (2014). http://www.naclc.org.au/resources/Joint_NGO_Report_on_Australia_s_Human_ Rights_Record_Final.pdf (accessed July, 2018).

82. Ibid, p. 2.

83. Ibid.

84. Ibid.

85. Ibid, p. 3.

86. Ibid, p. 13.

87. Australia's National Action Plan (2012), https:/lib.ohchr.org/HRBodies/UPR/Documents/ Session10/AU/ImplementationAustralia_1.pdf (accessed July, 2018).

88. These 3 documents are available on the website of the Human Rights Council, at: https:// www.ohchr.org/en/hrbodies/upr/pages/uprimplementation.aspx (accessed July, 2018).

89. Australia's National Action Plan (2012), https://lib.ohchr.org/HRBodies/UPR/Documents/ Session10/AU/ImplementationAustralia_1.pdf (accessed July, 2018), p. 24.

90. National report submitted in accordance with paragraph 5 of the annex to Human Rights Council resolution 16/21, Australia, A/HRC/WG.6/23/AUS/1, 7 August 2015.

91. Ibid, para. 13.

92. Ibid, para. 40 .

93. Ibid, para. 39.

94. Ibid, para. 115 .

95. Ibid, para. 116 .

96. Summary prepared by the Office of the United Nations High Commissioner for Human Rights in accordance with paragraph 15 (c) of the annex to Human Rights Council resolution 5/1 and paragraph 5 of the annex to Council resolution 16/21, Australia, A/HRC/WG.6/23/ AUS/3, 10 August 2015.

97. Ibid, para. 66 .

98. Ibid, para. 67.

99. Ibid, para. 66 . 
100. Compilation prepared by the Office of the United Nations High Commissioner for Human Rights in accordance with paragraph 15 (b) of the annex to Human Rights Council resolution 5/1 and paragraph 5 of the annex to Council resolution 16/21, Australia, A/HRC/WG.6/23/ AUS/2, 31 August 2015.

101. Ibid, para. 60 .

102. Commonwealth of Australia, 'Brining them Home. Report of the National Inquiry into the Separation of Aboriginal and Torres Strait Islander Children from Their Families' (1997), https://www.humanrights.gov.au/sites/default/files/content/pdf/social_justice/bringing them_home_report.pdf (accessed: July, 2018).

103. Compilation prepared by the Office of the United Nations High Commissioner for Human Rights in accordance with paragraph 15 (b) of the annex to Human Rights Council resolution 5/1 and paragraph 5 of the annex to Council resolution 16/21, Australia, A/HRC/WG.6/23/ AUS/2, 31 August 2015, para. 60.

104. Ibid, para. 61 .

105. UPRInfo, 'Database of Recommendations', https://www.upr-info.org/database/index.php? \&limit $=0 \& f$ _SUR $=9 \& \mathrm{f} \_S M R=$ All\&order $=$ \&orderDir $=$ ASC\&orderP $=$ true\&f_Issue $=$ 26\&searchReco=\&resultMax=100\&response $=$ \&action_type $=\&$ session $=1-2-3-4-5-6-7-8-9$ 10-11-12\&SuRRgrp $=\&$ SuROrg $=\& S M R R g r p=\& S M R O r g=\&$ pledges $=$ RecoOnly $\quad$ (accessed July, 2018).

106. Ibid.

107. Reconciliation Australia, 'The United Nations Declaration on the Rights of Indigenous Peoples', https://www.reconciliation.org.au/wp-content/uploads/2017/11/ReconciliationAustralia-United-Nations-Declaration-on-the-Rights-of-Indigenous-Peoples-UNDRIP.pdf (accessed July, 2018).

108. Address to the 4th session of the UN Human Rights Council by UN Secretary-General, Ban Ki-moon, www.un.org/apps/news/story.asp?NewsID=21834\#.UYD0q6JayPc (accessed July, 2018).

109. A.M. Abebe, 'Of Shaming and Bargaining: African States and the Universal Periodic Review of the United Nations Human Rights Council', Human Rights Law Review 9, no. 1 (2009): 1$35,19$.

110. UN Watch, Mutual Praise Society. Country scorecard and evaluation of the Universal Periodic Review system of the UN Human Rights Council. Presented at the United Nations Human Rights Council, February 6, 2009.

111. D. Frazier, 'Evaluating the Implementation of UPR Recommendations: A Quantitative Analysis of the Implementation Efforts of Nine UN Member States', https://www.upr-info. org/sites/default/files/general-document/pdf/-david_frazier_paper_upr_implementation_ 2011-2.pdf (accessed February, 2018).

112. See, for example, R. Brett, A Curate's Egg, Quaker United Nations Office August 2009, http:// www.quno.org/sites/default/files/resources/A\%20Curate\%27s\%20Egg.pdf (accessed July, 2018).

113. See, for example, Human Rights Watch, Curing the Selectivity Syndrome. The 2011 Review of the Human Rights Council, https:/www.hrw.org/sites/default/files/reports/ hrc0610webwcover.pdf (accessed July, 2018) and E. McMahon, The Universal Periodic Review: A Work in Progress. An Evaluation of the First Cycle of the New UPR Mechanism of the United Nations Human Rights Council, 2012, http://library.fes.de/pdf-files/bueros/ genf/09297.pdf (accessed July, 2018).

114. See, for example, UPRInfo, Universal Periodic Review; On the Road to Implementation, (2012), www.upr-info.org (accessed July, 2018). A number of studies have reviewed the UPR from the perspective of children's rights. See, for example, Children's Rights Information Network, Status of Children's Rights in the UPR, (November, 2010), www.crin. org/resources/infoDetail.asp?ID=22015\&flag=report\#vv (accessed February, 2018), J. Jolley, An Academic Study of the Universal Periodic Review (UPR) from the Perspective of Children's Rights, (2012), https://resourcecentre.savethechildren.net/sites/default/files/ documents/6982.pdf (accessed July, 2018), and N. Higgins, 'Advancing the Rights of 
Minorities and Indigenous Peoples: Getting UN Attention via the Universal Periodic Review', Netherlands Quarterly of Human Rights 34 (2014): 379-407. Other reviews have concentrated on the experience of specific States of the UPR, see, for example, E. Dewhurst, and N. Higgins, 'Ireland and the Universal Periodic Review: A Two way Process', Socio-Legal Studies Review 1 (2012): 140-51.

115. See E. McMahon, The Universal Periodic Review: A Work in Progress. An Evaluation of the First Cycle of the New UPR Mechanism of the United Nations Human Rights Council, 2012, http://library.fes.de/pdf-files/bueros/genf/09297.pdf (accessed February, 2018).

116. See H. Fridlund, 'A butterfly effect-steps to improve UPR implementation', OpenGlobalRights, January 2017, https://www.openglobalrights.org/butterfly-effect-steps-to-improveupr-implementation/ (accessed July, 2018).

117. Office of the Attorney General and Department of Justice, 'Universal Periodic Review, 2nd Cycle Implementation Matrix 2015-2019', https://www.upr-info.org/sites/default/files/ general-document/pdf/kenya_2nd_cycle_final_matrix_2016.pdf (accessed July, 2018).

118. See https://www.youtube.com/watch?v=5R-spwu0YXc (accessed July, 2018).

119. However, it is a very positive move that indigenous peoples are establishing a voice in certain UN organs, by means of UN General Assembly Resolution 71/321 (2017), Enhancing the Participation of Indigenous Peoples' Representatives and Institutions in Meetings of Relevant United Nations Bodies on Issues Affecting Them.

120. S. Gujadhur and M. Limon for Universal Rights Groups, Towards the Third Cycle of the UPR: Stick or Twist (2016), https://www.universal-rights.org/wp-content/uploads/2016/07/ URG_UPR_stick_or_twist.pdf (accessed July, 2018), p. 4.

121. IWIGA, The Indigenous World 2011, IWIGA, Copenhagen (2011), 515.

122. J. Cooper, 'Universal Periodic Review: A Potent Process for the Realization of Human Rights in Indigenous Homelands', Cultural Survival Quarterly Magazine 38(2) (2014), https://www. culturalsurvival.org/publications/cultural-survival-quarterly/universal-periodic-reviewpotent-process-realization-0 (accessed July, 2018).

123. Reconciliation Australia, 'The United Nations Declaration on the Rights of Indigenous Peoples (UNDRIP)', https://www.reconciliation.org.au/wp-content/uploads/2017/11/ Reconciliation-Australia-United-Nations-Declaration-on-the-Rights-of-IndigenousPeoples-UNDRIP.pdf (accessed July, 2018).

\section{Disclosure statement}

No potential conflict of interest was reported by the author.

\section{Notes on contributor}

Noelle Higgins is a Senior Lecturer in the Law Department at Maynooth University, Ireland. She undertook her $\mathrm{PhD}$ on the topic of wars of national liberation at the Irish Centre for Human Rights, NUI Galway. She teaches and researches in a variety of fields of public international law, particularly human rights law and international criminal law. She was previously a member of the Irish Department of Foreign Affairs and Trade NGO Human Rights Committee 2010-2012 and Vice-Chair of the Royal Irish Academy's Ethical, Political, Legal and Philosophical Studies Committee. 